\title{
The Identification of the SARS-CoV-2 Whole Genome: Nine Cases Among Patients in Banten Province, Indonesia
}

\author{
Chris Adhiyanto ${ }^{1 *}$ (D) , Laifa A. Hendarmin ${ }^{1}$ (D) Erike A. Suwarsono ${ }^{1}$ (D) , Zeti \\ Harriyati $^{1}$, Suryani ${ }^{1}$, Rini Puspitaningrum ${ }^{2}$ (D) and Dennis Nurjadi ${ }^{3}$ (D) \\ ${ }^{1}$ Medical Research Laboratory, Faculty of Medicine, Syarif Hidayatullah State Islamic University, Jakarta, Indonesia. \\ ${ }^{2}$ Faculty of Math and Science, Universitas Negeri Jakarta, Jakarta, Indonesia. \\ ${ }^{3}$ Department of Infectious Diseases, Medical Microbiology and Hygiene, Heidelberg University Hospitals, \\ Heidelberg, Germany.
}

\begin{abstract}
Severe acute respiratory syndrome coronavirus 2 (SARS-CoV-2) is the strain of virus that causes coronavirus disease 2019 (COVID-19), the respiratory illness responsible for the current pandemic. Viral genome sequencing has been widely applied during outbreaks to study the relatedness of this virus to other viruses, its transmission mode, pace, evolution and geographical spread, and also its adaptation to human hosts. To date, more than 90,000 SARS-CoV-2 genome sequences have been uploaded to the GISAID database. The availability of sequencing data along with clinical and geographical data may be useful for epidemiological investigations. In this study, we aimed to analyse the genetic background of SARS-CoV-2 from patients in Indonesia by whole genome sequencing. We examined nine samples from COVID-19 patients with RT-PCR cycle threshold (Ct) of less than 25 using ARTIC Network protocols for Oxford Nanopore's Gridi On sequencer. The analytical methods were based on the ARTIC multiplex PCR sequencing protocol for COVID-19. In this study, we found that several genetic variants within the nine COVID-19 patient samples. We identified a mutation at position 614 P323L mutation in the ORF1ab gene often found in our severe patient samples. The number of SNPs and their location within the SARS-CoV-2 genome seems to vary. This diversity might be responsible for the virulence of the virus and its clinical manifestation.
\end{abstract}

Keywords: SARS-CoV-19, COVID-19, RNA, Whole genome, SNP, Banten, Indonesia

*Correspondence: chrisbiomed@uinjkt.ac.id
(Received: March 31, 2021; accepted: May 26, 2021)
Citation: Adhiyanto C, Hendarmin LA, Suwarsono EA, et al. The Identification of the SARS-CoV-2 Whole Genome: Nine Cases
Among Patients in Banten Province, Indonesia. J Pure Appl Microbiol. 2021;15(2):936-948. doi: 10.22207/JPAM.15.2.52
@ The Author(s) 2021. Open Access. This article is distributed under the terms of the Creative Commons Attribution 4.0 International License which
permits unrestricted use, sharing, distribution, and reproduction in any medium, provided you give appropriate credit to the original author(s) and
the source, provide a link to the Creative Commons license, and indicate if changes were made. 


\section{INTRODUCTION}

The pandemic caused by the severe acute respiratory syndrome coronavirus 2 (SARS-CoV-2) is a global health issue. The first infection with this novel RNA coronavirus was reported in Wuhan, China, at the end of 2019, and since then it has spread throughout the world ${ }^{1,2,3}$. In Indonesia, the first case was identified in early March 2020, with reported cases of foreign nationals suffering from COVID-19. Gradually, the incidence of cases increased, especially in large cities ${ }^{4,5,6}$.

At the end of October 2020, COVID-19 cases in Indonesia had reached more than 350,000 , with an average of nearly 4000 new cases per day. However, information about the SARS-CoV 2 RNA virus in Indonesia is still scant ${ }^{7,8}$.

As a medical faculty with a laboratory for SARS-CoV-2 examination, we have the opportunity to perform genomic analysis of SARS-CoV-2 samples from patients who have unfavourable clinical presentations. Using Minion Nanopore technology, we identified the genome of the SARSCoV-2 from nine patients in Banten Province.

\section{MATERIALS AND METHODS \\ Sample collection}

Since June 2020, The Medical Research Laboratory, Faculty of Medicine, Syarif Hidayatullah State Islamic University as become part of the COVID-19 Laboratory Examination Network for Banten, West Java, Indonesia. On average, we have received 400-500 samples every week, amounting to about 4000 samples by the end of October 2020 , with a positivity rate of $25 \%(1000 / 4000$ samples). We received samples from hospitals, clinics and public health centres in the Banten area to us in viral transport medium (VTM).In this study, we collected and sequenced nine RNA samples from these patients.

\section{Ethical clearance}

Ethical clearance was issued by the Ethic Committee of the Faculty of Medicine UIN Syarif Hidayatullah Jakarta (No.B-005/F12/KPK/ TL.00/02/2021) and each specimen was submitted to our laboratory along with informed consent from the patient.

\section{RNA extraction}

Two hundred $\mu \mathrm{L}$ of VTM containing patient samples were transferred into a tube containing $600 \mu \mathrm{L}$ of TRI-Zol solution (TRI
Reagent ${ }^{\circledast}$ ) and shaken until homogeneous. The homogeneous samples were centrifuged and the supernatants transferred into RNase-free tubes. Each supernatant in its RNase-free tube was mixed with $600 \mu \mathrm{L}$ of ethanol (95-100\%) and gently shaken. The mixture was transferred to a Zymo$\mathrm{Spin}^{\mathrm{TM}} \mathrm{IC}$ column in a collection tube, centrifuged, and the collection liquid discharged. Subsequently, $400 \mu \mathrm{L}$ of RNA wash buffer was added into the column and centrifuged. This was followed by $5 \mu \mathrm{L}$ of DNase I and $35 \mu \mathrm{L}$ of DNA digestion buffer being added into the column matrix and incubated for 15 minutes at room temperature (RT). Then, $400 \mu \mathrm{L}$ of Direct-Zol ${ }^{\mathrm{TM}}$ RNA prewash was added, centrifuged and the liquid flowing into the collection tube removed. Next, $700 \mu \mathrm{L}$ of RNA wash buffer was added to the column and centrifuged for two minutes to ensure that the wash buffer had transferred into the collection tube and the lysate had passed through the membrane. After that, the column was transferred into an RNase-free tube and $50 \mu \mathrm{L}$ of DNase/RNase-free water was added to elute the RNA, followed by centrifugation so that the RNA flowed into the RNase-free tube.

RNA dissolved by $50 \mu \mathrm{L}$ DNase/RNase-free water was stored at $-80^{\circ} \mathrm{C}$ if not used immediately. qRT-PCR analysis

We conducted qRT-PCR by using one step reaction Biosensor Standard M SARS-CoV-2 PCR (Chungcheongbuk-do, Republic of Korea) in a Roche LC480 II machine. The protocol was as described in the manufacture's insert kit with targets of ORF1ab gene and $E$ gene.

\section{SARS-Cov-2 sequencing}

Out of 6000 samples, we randomly selected nine samples from patients who were positive for COVID-19 and had a cycle threshold (Ct) value of between 15 and 25 . All samples were measured for concentration and purity prior to sequencing.

All samples were prepared using ARTIC Network protocols and analytic methods ${ }^{9}$. The protocols and analyses were based on the ARTIC multiplex PCR sequencing protocol for COVID-19 devised by Josh Quick. The protocol generates 400 bp amplicons in a tiled fashion across the whole COVID-19 genome.

Oxford Nanopore's GridION sequencer was operated using MinKNOW version 20.06.9 and MinKNOW core version 4.0.3. High accuracy 
base-calling was conducted using Guppy ${ }^{10}$ version 4.0.11. All generated reads were assembled using EPI2ME Labs platform employing ARTIC workflow. After preparation using ARTIC multiplex $P C R$, all samples were analysed using GridION operated by MinKNOW software. Base-calling was performed using Guppy with high accuration mode. Raw reads were assembled employing EPI2ME Labs software. All sequencing and bioinformatic workflows are shown in Figures 1 and 2.

\section{RESULTS}

In Indonesia, the number of COVID-19 patients reached more than 500,000 by the end of November $2020^{1-8,11}$. Their clinical presentations varied from asymptomatic to severe.

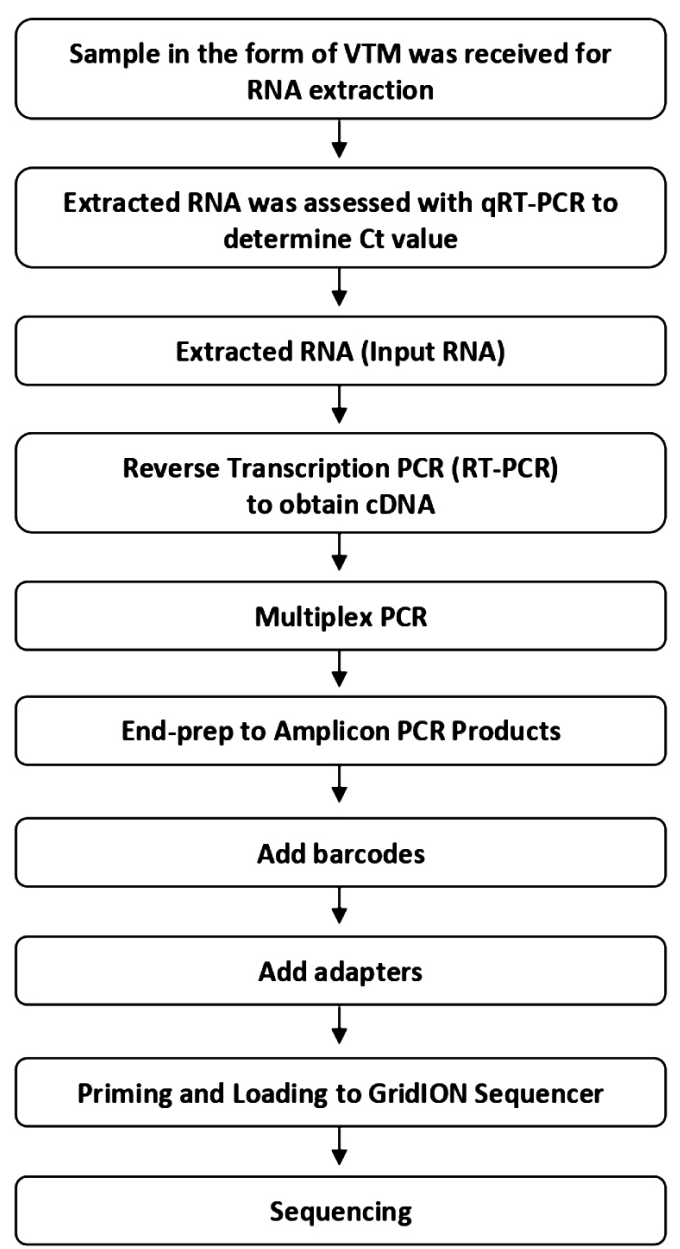

Fig. 1. Experimental workflow of sequencing
In this study, we examined the whole genome of SARS-CoV-2 from nine COVID-19 patients using Nanopore's GridION sequencer. We found variations in the changes of nucleotide bases in the exon and intergenic virus regions. The clinical characteristics of these patients are summarized in Table 1 . Most of them had fever, anosmia, dry cough, and fatigue and did not have comorbidities.

We found many missense and synonymous or silent mutations in the samples, as shown in Table 2. One sample was found to have a nucleotide deletion while the other changes were

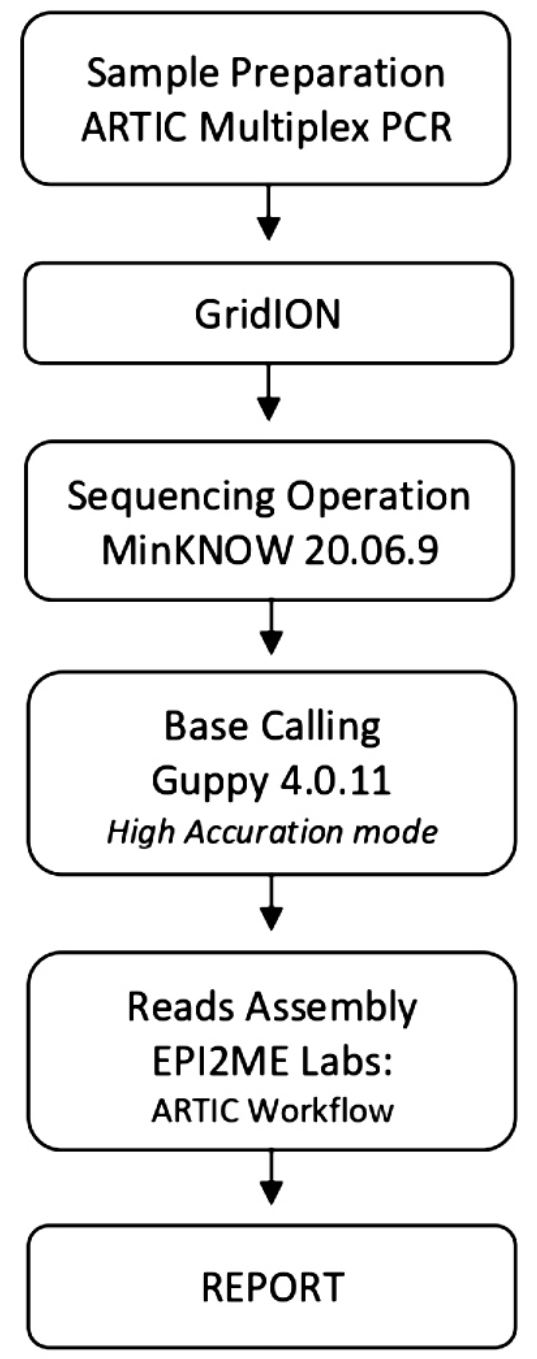

Fig. 2. Bioinformatic workflow ${ }^{9,10}$ 


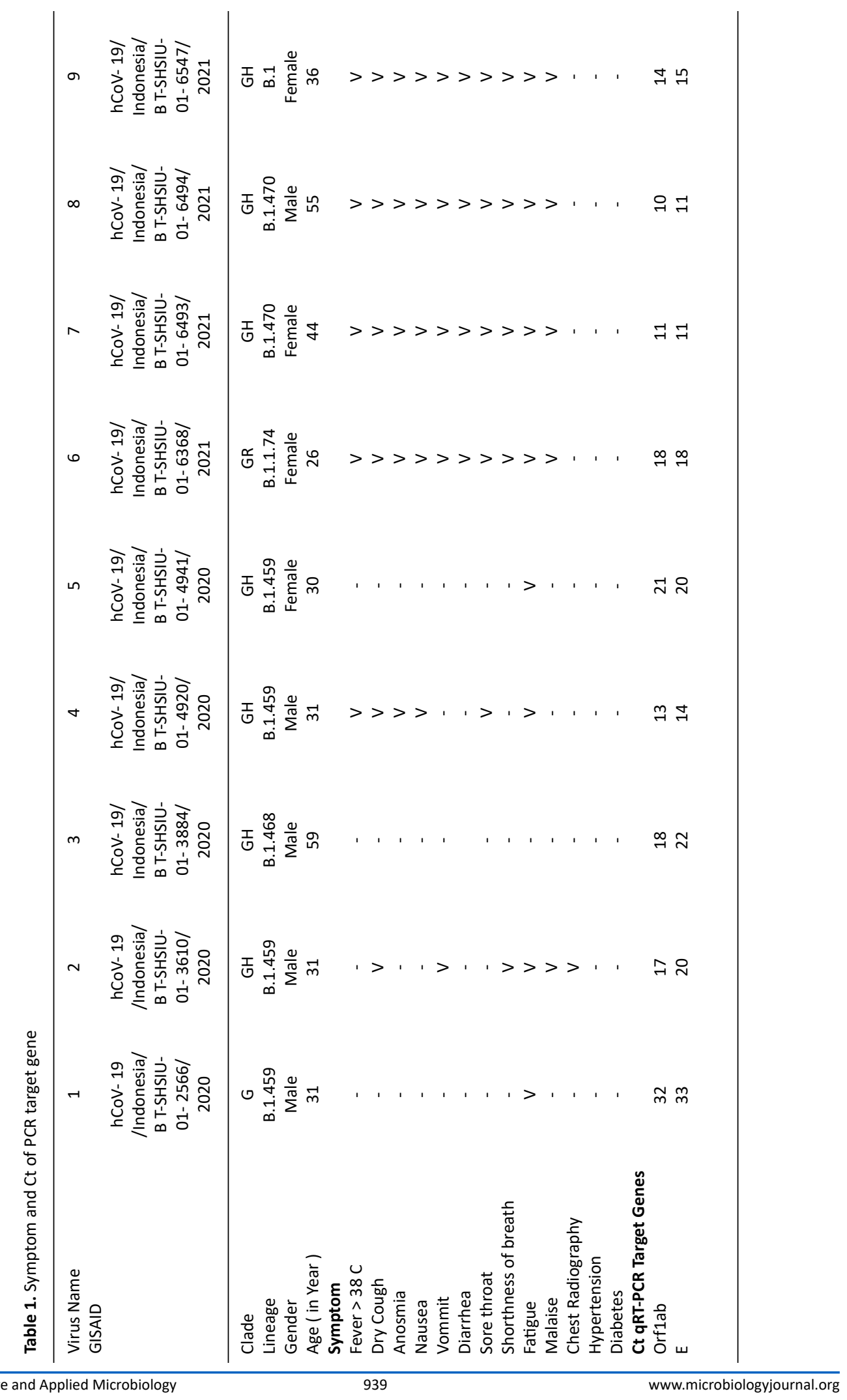




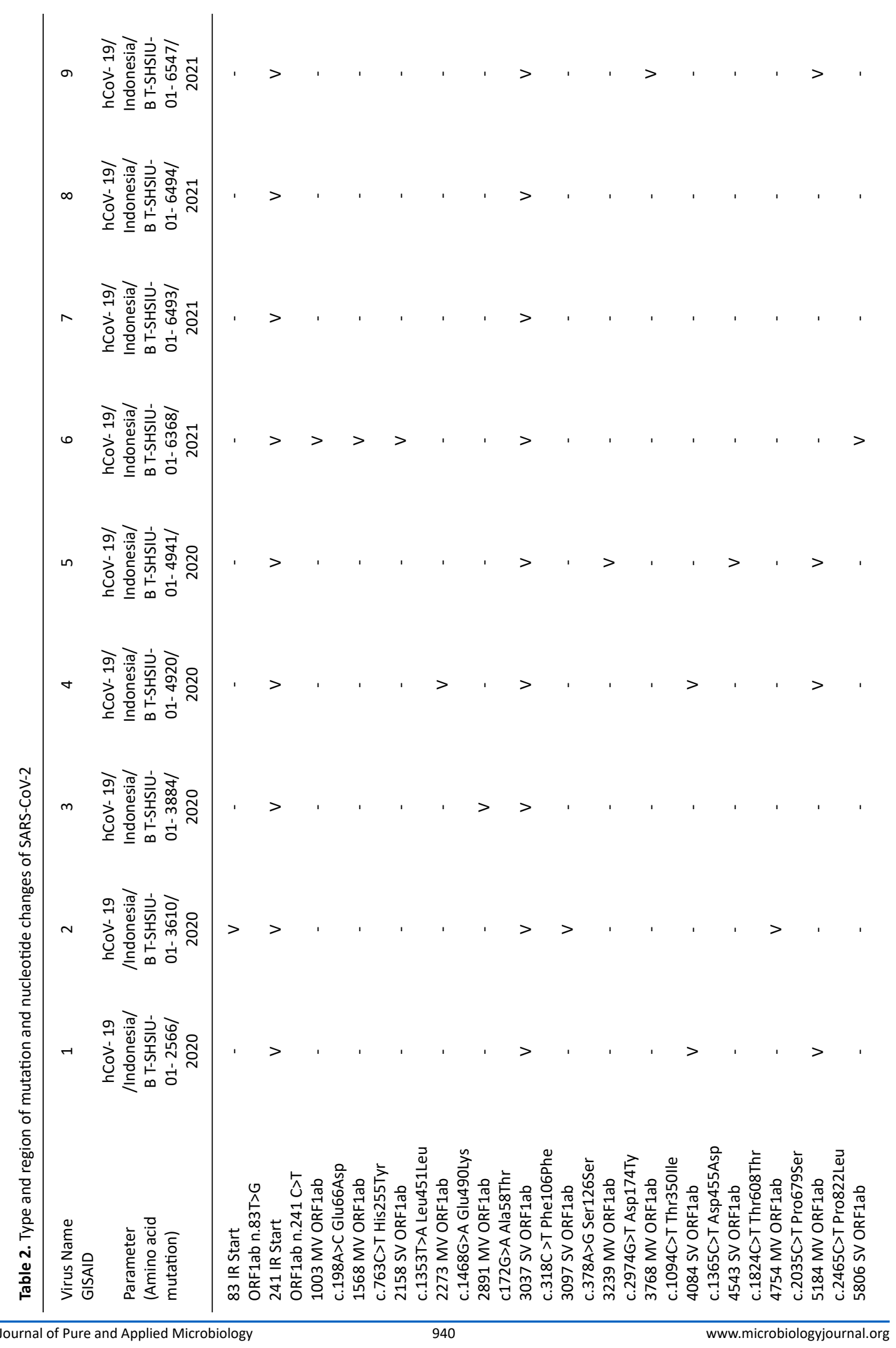




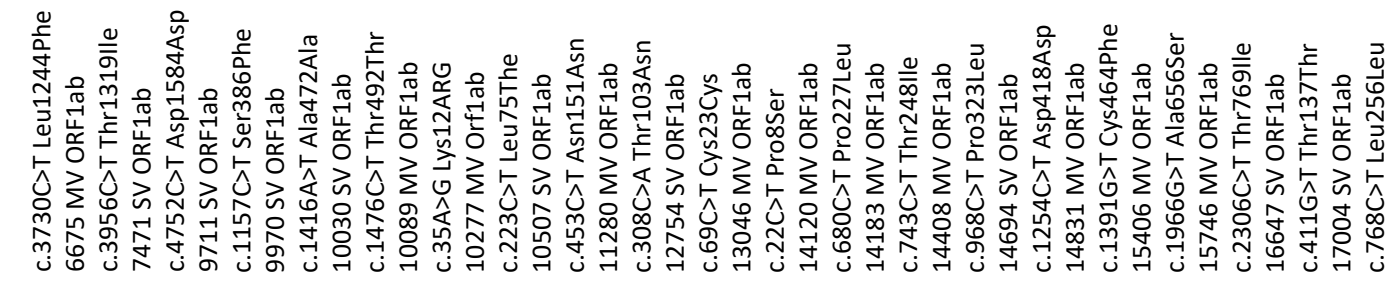

Journal of Pure and Applied Microbiology

941 


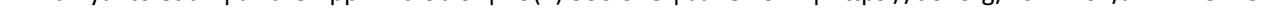




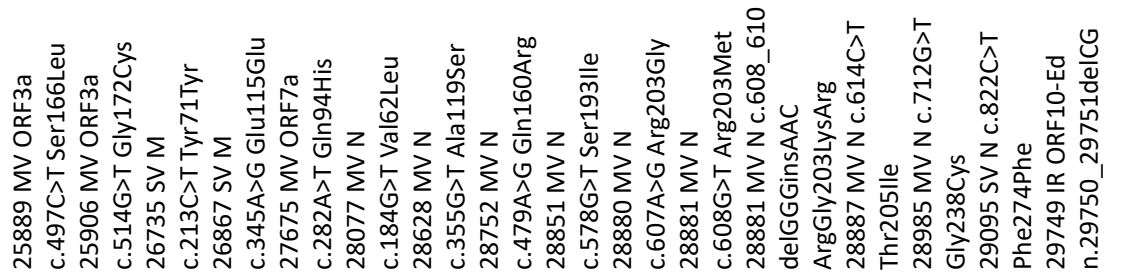


nucleotide substitutions. Moreover, we detected the gene area and amino acids that changed in these nine samples (Table 2) and most of the changes were found in the ORF1ab target gene. All of these SARS-CoV-2 sequences had already been submitted to GISAID.

The bioinformatic analysis using EPI2ME software revealed numbers of SNP variants ranging from 13 to 23 and one variant being a deletion.

As shown in Table 2, the most common nucleotide changes in our nine patients were $\mathrm{C}>\mathrm{T}$ at nucleotide positions 241; 3037; 14408; 26735 and $A>G$ at nucleotide position 23403. The codon and amino acid changes found in most samples were CCT $>C T T . P>L$ proline to leucine, and GAT> GGT.D $>\mathrm{G}$ aspartate to glycine.

\section{DISCUSSION}

It has been reported that the SARS-CoV-2 genome is similar to that of the SARS-CoV virus that caused the epidemic in 2003. Overall, the protein characteristics for SARS-CoV have been identified, consisting of polyproteins Orf1a and Orf1ab; four structural proteins spike (S), envelope $(E)$, membrane protein(M), and nucleocapsid (N); and eight accessory protein forms: Orf3a, Orf3b, Orf6, Orf7a, Orf7b, Orf8a, Orf8b, and Orf9. Accessory proteins, besides their function in viral replication, play a role in the interaction of the virus with its host.

In SARS-CoV-2,there are 11 proteins: Orf1ab, Orf2 (referred to as S protein); Orf3a and Orf4 are E proteins; Orf5 is the M protein; Orf6, Orf7a, Orf7b, Orf8, and Orf9 are N proteins, and finally Orf10 ${ }^{12-17}$. In SARS-CoV-2, the Orf1ab gene expresses polyproteins, consisting of 16 nonstructural proteins (NSP). NSP1 is known as an inhibitor of host gene expression binding to the host's 40S ribosome which results in selective degradation of the host's mRNA so that the viral mRNA can bind ${ }^{18,19}$. NSP2 has the ability to influence the host cell environment by binding to prohibitin proteins (PHB) 1 and 2 of host cells and resulting in cell cycle progression, cell migration, cellular differentiation, apoptosis and mitochondrial biogenesis ${ }^{20}$. NSP3 is a protease protein that plays a role in the release of essential viral proteins. The interaction of NSP3 and NSP4 is very important for viral replication ${ }^{21,22}$.

Mutations in viruses aim to adapt to the environment and new hosts. The capacity of viruses to adapt to their new hosts and environments depends to a great extent on their ability to produce diversity in a short period of time. Thus, the rate of spontaneous mutation between viruses varies widely due to the diversityproducing element encoded by the virus and its host. Viral diversity can also occur in response to certain selective stresses. RNA viruses have the ability to mutate faster than DNA viruses. Understanding the rate of virus mutation has implications for treatment, the development of drug resistance, immunity, pathogenesis and vaccination in efforts to control the disease ${ }^{23,24}$.

The most common types of SNPs detected in this study are missense and synonymous variants in the exon area. Missense mutations in the exon can affect codon changes for amino acids in the translation process. The effects of synonymous or silent mutations will affect post-transcriptional mRNA processes ${ }^{25-28}$. Such nucleotide mutations in the exon region enable changes in the amino acid sequence and alterations of the tertiary structure of the target protein.

Moreover, the intergenic region is an area where transcriptional enhancer sites related to regulatory functions are often found. Mutations in this area will affect the regulatory processes of the gene $\mathrm{e}^{29,30-33}$. Therefore, all of these changes can result in the phenotypic diversity of the virus. It has been shown that mutations in the Orf area can affect the translation termination process ${ }^{34}$. Bali et al. demonstrated that synonymous mutations will affect protein function ${ }^{35}$.

Overall, missense mutation in the codon region was most prevalent in our samples. Changes due to missense will change the amino acid code and ultimately the amino acid that will be translated. Changes of proline $(P)$ to leucine $(L)$, and aspartate (D) to glycine $(G)$ were those found in all of our samples.

Missense variants can affect the tertiary structure of a protein depending on the nature or character of the amino acids that form the polypeptide sequence. Changes of polar amino acids to non-polar, charged or neutral, will affect the properties of the proteins. We found 15 missense variants in the Orf1ab gene in our samples, and any change in amino acid residues will affect the structure of the Orf1ab polyprotein, which is 
known toplay a role in adaptation and virulence in its host. Graham et al. have described the possible role of Orf1ab in the pathogenic immune response of viruses and their hosts ${ }^{36}$. The Orf1ab polyprotein consists of 16 non-structural proteins (NSP) ${ }^{37}$. Non-structural proteins have a role in directing viral assembly after the virus invades the host cell, including viral transcription and replication, proteolytic processing, suppression of immune responses and expression of host genes ${ }^{37-41}$. One of our samples had an alteration in the amino acid residue glutamate to lysine at position 2273 of Orf1ab gene at amino acid position 670 (part of NSP3). The glutamate residue is a polar amino acid and the acid is replaced by an alkaline lysine residue. Changes in the sequence of amino acids in a polypeptide or protein in an organism can have a positive or negative effect on the organism, one of which is the ability of the virus to adapt to its host. NSP3 plays many roles in the viral life cycle as it can act as a scaffold protein to interact with itself and to bind to other viral NSPs or host proteins. NSP3 is also very important for the formation of replication transcription complex (RTC). RTC is linked to the host endoplasmic reticulum membrane to produce convoluted membranes and double membrane vesicles in SARS-CoV-2. Changes in the nucleotide bases or amino acids of NSP3 are likely to have an influence in the role of NSP3 ${ }^{42}$. However, comprehensive information regarding the association of Glu670Lys with the virulence of SARS-CoV-2 is needed.

The conversion of aspartate residue to glycine residue at position 614 (Asp614Gly) of the $S$ gene was found in all of our samples. The $S$ gene plays a role in the formation of the spike protein (S), such that the S protein will be recognized and will bind to the host receptor so that the SARS-CoV-2 virus can enter the host cell. Several studies have reported a possible link between changes in D614G and the ability of the virus to infect host cells. This variant mutation was found at multiple geographic levels ${ }^{43-47}$. The aspartate residue at position 614 lies outside the receptor-binding domain or RBD and does not change the affinity of the S protein to bind ACE2, but is thought to play a role in ACE2-mediated cell transduction. In addition, it appears that $\mathrm{S}$ protein played a key role in the evolution of the coronavirus in circumventing the host's immune mechanism $^{43,47-49}$

It is interesting that we also found another variant besides D614G in the S protein in two of our patients, namely $\mathrm{Q} 677 \mathrm{H}^{50}$. This variant was first reported in Surabaya, East Java, and was also found in our patients living in Banten, West Java. Personal communication with patients provides information on the possibility of contact with relatives or family members who are from East Java. This shows the importance of lockdown measures during the SARS-CoV-2 pandemic to limit or prevent the widespread of highly virulent virus variants.

In addition to mutations in the $S$ protein, we observed that patients with severe conditions had missense mutations in spikeD614G, in NS3(Orf3a)Q57H, and NSP12 (Orf1ab) P323L. Majumdar et al. report an association between mutations in Orf3a and manifestations of SARSCoV-2 immuno-pathogenic infection ${ }^{51}$. Wu et al. report that mutations in $\mathrm{Q} 57 \mathrm{H}$ cause a dramatic change in protein structure that would affect the binding affinity for antiviral proteins ${ }^{52}$. The ORF3a protein is one of the largest accessory proteins in SARS-CoV-2 and is a link in the pathogenesis of COVID-1953. The mutation in the NSP12 as RdRp catalyses the replication of RNA and could affect the speed of viral replication ${ }^{54}$. The combination of three mutations in this region could lead to more severe clinical presentation and fatality of COVID-19.

Mutations are expected as natural events within the viral life cycle. Viral adaptation to the host usually results in higher transmission potential, as has been observed for SARS-CoV, MERS, and influenza. The pattern and time course of mutations in virus genomes are critical in estimating phylogenetic trees, which, in turn, depict the epidemic course effectively in real time. Mutations can provide information for understanding emerging outbreaks. The field of genomic epidemiology is presently employed in the mitigation and control of the SARS-CoV-2 outbreak ${ }^{55}$.

\section{CONCLUSION AND FUTURE PROSPECTS}

This study has shown several changes in the nucleotide sequence of SARS-CoV-2 resulting in different variants. The changes that occur cause the virus to survive and may lead to detrimental impact 
on the host. Therefore, molecular characterization and epidemiological data for SARS-CoV-2 variations are needed to monitor population shifts and to promptly identify emerging and more virulent variants. More importantly, vaccine efficacy against SARS-CoV-2 variants should be verified.

\section{ACKNOWLEDGMENTS}

The authors acknowledge their institutes and universities. We are grateful to Prof. HJ Freisleben for his valuable comments on this manuscript and Genetics Science for assisting in lending Nanopore Minions so that we could carry out this research.

\section{CONFLICT OF INTEREST}

The authors declare that there is no conflict of interest.

\section{AUTHORS' CONTRIBUTION}

All authors listed have made substantial, direct and intellectual contributions to the work, and approved it for publication.

\section{FUNDING}

None.

\section{DATA AVAILABILITY}

All data set generated or analyzed during this study are included in the manuscript.

\section{ETHICS STATEMENT}

Not applicable.

\section{REFERENCES}

1. Mackenzie JS, Smith DW. Covid-19: a novel zoonotic disease caused by a coronavirus from China: what we know and what we don't. Microbiol Aust. 2020;MA20013. doi: 10.1071/MA20013

2. Zheng J. SARS-CoV-2: an emerging Coronavirus that causes a global treat. Int J Biol Sci. 2020;16(10):16781685. doi: 10.7150/ijbs. 45053

3. Hu B, Guo H, Zhou P, Shi Z. Characteristic of SARS-CoV-2 and COVID-19. Nat Rev Microbiol. 2021;19:141-154. doi: 10.1038/s41579-020-00459-7

4. Ariawan I, Jusril H. COVID-19 in Indonesia: Where are we?. Acta Med Indones. 2020;52(3):193-195. PMID: 33020329

5. Van Empel G, Mulyanto J, Wiratama BS. Undertesting of COVID-19 in Indonesia: what has gone wrong? J Glob Health. 2020;10(2):020306. doi: 10.7189/ jogh.10.020306

6. Halim DA, Kurniawan A, Agung FA, et al. Understanding of young people about COVID-19 during early outbreak in Indonesia. Asia Pac J Public Health. 2020;32(67):363-365. doi: 10.1177/1010539520940933

7. Covid-19 di Indonesia: Kasus tembus 500.000 (Covid-19 in Indonesia: Cases penetrating 500,000, experts say the spread of the virus is' increasingly undetected, the real number could be millions) https://www.bbc.com/ indonesia/indonesia-55046484

8. COVID-19 in Indonesia on October 31, 2020. Report of the Ministry of Health of the Republic of Indonesia. https://www.kemkes.go.id/resources/download/infoterkini/covid\%20dalam\%20angka/covid\%20dalam\%20 angka\%20-\%2031102020.pdf

9. Tyson JR, James P, Stoddart D, et al. Improvements to the ARTIC multiplex PCR method for SARS-CoV-2 genome sequencing using nanopore. BioRxiv. 2020. doi: 10.1101/2020.09.04.283077

10. Wick RR, Judd LM, Holt KE. Performance of neural network basecalling tools for Oxford Nanopore sequencing. Genome Biol. 2019;20: 129. doi: 10.1186/ s13059-019-1727-y

11. Positive COVID-19 Cases in Indonesia Add 6,267 People, 3T and 3M Efforts continue to be intensified. Report of the Ministry of Health of the Republic of Indonesia. https://www.kemkes.go.id/article/ view/20113000001/kasus-positif-covid-19-diindonesia-tambah-6-267-orang-upaya-3t-dan-3mterus-digencarkan.html

12. Laha S, Chakraborty J, Das S, Manna SK, Biswas $S$, Chatterjee R. Characterizations of SARS-CoV-2 mutational profile, spike protein stability and viral transmission. Infect Genet Evol. 2020;85:104445. doi: 10.1016/j.meegid.2020.104445

13. Naqvi AAT, Fatima $K$, Mohammad T, et al. Insights into SARS-CoV-2 genome, structure, evolution, pathogenesis and therapies: Structural genomics approach. Biochim Biophys Acta Mol Basis Dis. 2020;866(10):165878. doi: 10.1016/j.bbadis.2020.165878

14. YA Helmy, M Fawzy, A Elaswad, A Sobieh, SP Kenney, AA Shehata. The COVID-19 pandemic: a comprehensive review of taxonomy, genetics, epidemiology, diagnosis, treatment and control. J Cli Med. 2020;9(4):1225. doi: 10.3390/jcm9041225

15. Khailany RA, Safdar M, Ozaslan M. Genomic characterization of a novel SARS-CoV-2. Gene Rep. 2020;19:100682. doi: 10.1016/j.genrep.2020.100682

16. Abdelrahman Z, Li M, Wang X. Comperative review of SARS-CoV-2, SARS-CoV, MERS-CoV and influenza A respiratory viruses. Front Immuno. 2020;11:552909. doi: 10.3389/fimmu.2020.552909

17. Kaur M, Sharma A, Kumar S, Singh G, Barnwal RP. SARS-CoV-2: Insights into its structural intricacies and functional aspects for drug and vaccine development. Int J Biol Macromol. 2021;15(179):45-60. doi: 10.1016/j.ijbiomac.2021.02.212

18. Schubert K, Karousis ED, Jomaa A, et al. SARS-CoV-2 Nsp1 binds the ribosomal mRNA channel to inhibit translation. Nat Struct Mol Biol. 2020;27(10):959-966. doi: 10.1038/s41594-020-0511-8

19. Lapointe CP, Grosely R, Johnson AG, Wang J, Fernandez IS, Puglisi JD. Dynamic competition between SARSCoV-2 NSP1 and mRNA on the human ribosome 
inhibits translation initiation. Proc Natl Acad Sci USA. 2021;118(6):e2017715118. doi: 10.1073/ pnas. 2017715118

20. Cornillez-Ty CT, Liao L, Yates, JR, Kuhn P, Buchmeier MJ. Severe Acute Respiratory Syndrome Coronavirus NonStructural Protein 2 interacts with a host protein complex involved in mitochondrial biogenesis and intracellular signaling. J Virol. 2009; 83(19): 1031410318. doi: 10.1128/JVI.00842-09

21. Sakai $Y$, Kawachi K, Terada Y, Omori H, Matsuura $Y$, Kamitani W. Two-amino acids change in the nsp4 of SARS coronavirus abolishes viral replication. Virology. 2017;510:165-174. doi: 10.1016/j.virol.2017.07.019

22. Zhang J, Lan Y, Sanyal S. Membrane heist: Coronavirus host membrane remodeling during replication. Biochimie. 2020;179:229-236. doi: 10.1016/j. biochi.2020.10.010

23. Sanjuan R, Domingo-Calap P. Review: Mechanisms of viral mutation. Cell Mol Life Sci. 2016;73:4433-4448. doi: 10.1007/s00018-016-2299-6

24. Agudelo-Romero P, Carbonell P, Perez-Amador M, Elena SF. Virus adaptation by manipulating of host's gene expression. Plos One.2008;3(6):e2397. doi: 10.1371/journal.pone.0002397

25. Hunt RC, Simhadri VL, landoli M, Sauna ZE, KimchiSarfaty C. Exposing synonymous mutations. Trends Genet. 2014;30(7):308-321. doi: 10.1016/j. tig.2014.04.006

26. Sauna ZF, Kimchi-Sarfaty C, Ambudkar SV, Gottesman $\mathrm{MM}$. The sounds of silence: synonymous mutations affect function. Pharmacogenomics. 2007;8(6):527532. doi: $10.2217 / 14622416.8 .6 .527$

27. Komar AA. Silent SNPs: impact on gene function and phenotype. Pharmacogenomics. 2007;8(8):1075-1080. doi: $10.2217 / 14622416.8 .8 .1075$

28. Shastry BS. SNPs: Impact on Gene Function and Phenotype. Method Mol Biol. 2009;578:3-22. doi: 10.1007/978-1-60327-411-1_1

29. Khademi SMH, Sazinas P, Jelsbak L. Within-Host Adaptation Mediated by Intergenic Evolution in Pseudomonas aeruginosa. Genome Biol Evol. 2019;11(5):1385-1397. PMID: 30980662. doi: 10.1093/ gbe/evz083

30. Macintrye G, Yepes AJ, Ong CS, Vespoor K. Associating disease-related genetic variants in intergenic regions to the genes they impact. Peer J. 2014;2:e639. doi: 10.7717/peerj.639

31. Alderete JP, Jarrahian S, Geballe AP. Translational Effects of Mutations and Polymorphisms in a Repressive Upstream Open Reading Frame of the Human Cytomegalo virus UL4 Gene. J Virol. 1999;73(10):83308337. PMID: 10482583. doi: 10.1128/JVI.73.10.83308337.1999

32. Kumar P. Pandey R, Sharma P, et al. Integrated genomic view of SARS-CoV-2 in India. Wellcome Open Res. 2020;5:184. doi: 10.12688/wellcomeopenres.16119.1

33. Li H, Achour A, Bastarache L, et al. Integrative genomics analysi analyses unveil downstream biological effectors of disease-specific polymorphisms buried in intergenic regions. npj Gen Med. 2016;1:16006. doi: 10.1038/ npjgenmed.2016.6

34. Schierding W, Antony J, Cutfield W, et al. Intergenic
GWAS SNP are key components of spatial and regulatory network of human growth. Hum Mol Genet. 2016;25(15):3372-3382. doi: 10.1093/hmg/ddw165

35. Bali V, Bebok Z. Decoding Mechanisms by which Silent Codon Changes Influence Protein Biogenesis and Function. Int J Biochem Cell Biol. 2015; 64: 58-74. doi: 10.1016/j.biocel.2015.03.011

36. Graham RL, Spark JS, Eckerie LD, Sims AC, Denison MR. SARS coronavirus replicase proteins in pathogenesis. Virus Res. 2008;133(1):88-100. doi: 10.1016/j. virusres.2007.02.017

37. Yoshimoto FK. The Proteins of Severe Acute Respiratory Syndrome Coronavirus-2 (SARS CoV-2 or n-COV19), the Cause of COVID-19. The Prot J. 2020;39(6):198-216. doi: 10.1007/s10930-020-09901-4

38. Da Silva SJR, da Silva CTA, Mendes RPG, Pena L. Role of nonstructural proteins in the pathogenesis of SARS-CoV-2. J Med Virol. 2020;92(9)1427-1429. doi: 10.1002/jmv.25858

39. Banerjee AK, Blanco MR, Bruce EA, et al. SARS-CoV-2 Disrupts Splicing, Translation, and Protein Trafficking to Suppress Host Defenses. Cell. 2020;185(5):1325-1339. doi: 10.1016/j.cell.2020.10.004

40. Snijder EJ, Decroly, Ziebuhr J. The nonstructural proteins directing coronavirus RNA synthesis and processing. Adv Virus Res. 2016;96:59-126. doi: 10.1016/bs.aivir.2016.08.008

41. Denison MR, Graham RL, Donaldson EF, Eckerle LD, Barid RS. Coronaviruses: an RNA proofreading machine regulates replication fidelity and diversity. RNA Biol. 2011;8(2):270-279. doi: 10.4161/rna.8.2.15013

42. Lei J, Kusov $Y$, Hilgenfeld R. Nsp3 of coronaviruses: Structures and functions of a large multi-domain protein. Antiviral Res. 2018;149:58-74. doi: 10.1016/j. antiviral.2017.11.001

43. Volz E, Hill V, McCrone JT, et al. Evaluating the Effects of SARS-CoV-2 Spike Mutation D614G on Transmissibility and Pathogenicity. Cell. 2021;184(1):64-75. doi: 10.1016/j.cell.2020.11.020

44. Korber B, Fischer WM, Gnanakaran S, et al. Tracking Changes in SARS-CoV-2 Spike: Evidence that D614G Increases Infectivity of the COVID-19 Virus. Cell. 2020;182(4):812-827. doi: 10.1016/j.cell.2020.06.043

45. Zhang L, Jackson CB, Mou H, et al. The D614G mutation in the SARS-CoV-2 spike protein reduces S1 shedding and increases infectivity. BioRxiv. 2020. doi: 10.1101/2020.06.12.148726

46. Zhou B, Thao TTN, Hoffmann D, et al. SARSCoV-2 spike D614G variant confers enhanced replication and transmissibility. BioRxiv. 2020. doi: 10.1101/2020.10.27.357558

47. Groves DC, Rowland-Jones SL, Angyal A. The D614G mutations in the SARS-CoV-2 spike protein: Implications for viral infectivity, disease severity and vaccine design. Biochem Biophys Res Commun. 2021;538:104-107. doi: 10.1016/j.bbrc.2020.10.109

48. Begum J, Mir NA, Dev K, Buyamayum B, Wani MY, Raza $M$. Challenges and prospects of COVID-19 vaccine development based on the progress made in SARS and MERS vaccine development. Transbound Emerg Dis. 2021;68(3):1111-1124. doi: 10.1111/tbed.13804 49. Isabel S, Grana-Miraglia L, Gutierrez J, et al. 
Evolutionary and structural analyses of SARS-CoV-2 D614G spike protein mutation now documented worldwide. Sci Rep. 2020;10(1):14031. doi: 10.1038/ s41598-020-70827-z

50. Ansori ANM, Kharisma V D, Muttagin SS, Antonius $Y$, Parikesit AA. Genetic variant of SARS-CoV-2 isolates in Indonesia: Spike glycoprotein gene. J Pure Appl Microbiol. 2020;14(Suppl1):971-978. doi: 10.22207/ JPAM.14.SPL1.35

51. Majumdar P, Niyogi S. ORF3a mutation associated with higher mortality rate in SARS-CoV-2 infection. Epidemiol Infect. 2020;148:e262. doi: 10.1017/ S0950268820002599

52. Wu S, Tian C, Liu P, et al. Effects of SARS-CoV-2 mutations on protein structures and intraviral protein- protein interactions. J Med Virol. 2021;93(4):21322140. doi: 10.1002/jmv.26597

53. Hassan SS, Choudhury PP,Basu P, Jana SS. Molecular conservation and differential mutation on ORF3a gene in Indian SARS-CoV2 genomes. Genomics. 2020;112(5):3226-3237. doi: 10.1016/j. ygeno.2020.06.016

54. Vilar S, Isom DG. One year of SARS-CoV-2: How much has the virus changed? Biology. 2021;10:91. doi: 10.3390/biology10020091

55. Grubaugh ND, Petrone ME, Holmes CE. We shouldn't worry when a virus mutates during disease outbreaks. Nature Microbiology. 2020;5;529-530. doi: 10.1038/ s41564-020-0690-4 